\title{
"Sensory" interference in a word-color matching task
}

\author{
JOHN H. FLOWERS \\ University of Nebraska-Lincoln, Lincoln, Nebraska 68508
}

\begin{abstract}
Two experiments measured RTs for matching sequentially displayed color names to color patches. Experiment I demonstrated that printing the name in an incongruent color produced longer RTs than when the name was printed in black ink or a congruent colored ink, provided the time interval between the name display and the color patch display was brief (less than $100 \mathrm{msec}$ ). This interference was at tenuated with longer delays. In Experiment II, a wider range of irrelevant colors was combined with the name display, and RT was found to be correlated with the colorimetric dissimilarity between the name and the irrelevant color. These findings suggest competition between irrelevant sensory input and pictorial encoding of relevant linguistic input.
\end{abstract}

In the traditional version of the Stroop color-word test (Stroop, 1935), a large delay occurs in the oral naming of the color of an ink patch that is shaped to spell the name of another color. Many subsequent studies have demonstrated similar interference effects caused by competing sources of symbolic and sensory stimulus information in tasks which have used such diverse types of stimulus dimensions as numerosity (Morton. 1969), direction (Shor, 1970), and typeface style (Warren \& Lasher, 1974). While the majority of these studies have examined interference with oral simulus naming, incongruent sensory and symbolic stimulus information has been shown to produce substantial performance decrements in manual matching and classification tasks requiring no over rerbal response (Morton, 1969; Treisman \& Fearnley. 1969). Both Dalrymple-Alford and Azkoul (1972) and Morton (1969) have suggested that such tasks may involve at least coven stimulus naming, implying that the source of interference in such tasks arises from competition among linguistically encoded stimulus representations.

$A$ somewhat broader interpretation of sensoryverbal interference phenomena has been suggested by Treisman and Fearnley (1969) and elaborated by Dyer (1973a, p. 117). This model states that interference results when a perceptual task requires the transformation of a stimulus into a representation suitable for efficiently making the required response in the presence of a competing stimulus that is already closer to that form of encoding. Interference therefore occurs in the Stroop test. since the task requires subjects to transform the sensory impression of the ink color into a verbal name in the presence of a written color name. In addition, this "transforma-

Ihis reseatch was supported by grants from the University of veloriska Researeh Council, The author would like to thank F. N. Dyer and Allan Paivio for their suggestions and Julie Horney for a criticism at an earlier draft of this manuscript. Portions of this reseach "ere presented at the 1975 meeting of the Midwestern Probologisal Association. tion" interpretation is consistent with the failure of incongruent printed color names to slow the matching of simultaneously presented ink colors (Egeth, Blecker, \& Kamlet, 1969; Treisman \& Fearnley, 1969) and with the failure of incongruent ink colors to substantially disrupt the reading of color names (Stroop, 1935). Neither of these "within-analyzer" tasks requires the "across-analyzer" encoding required by the traditional Stroop test. By the same logic, one would predict that irrelevant sensory stimulus information, such as an incongruent ink color, would cause interference in a task requiring a transformation from a symbolic to a pictorial form of encoding, producing a "reverse-Stroop" effect. Provided such a task could be found, the interference might be termed image competition as opposed to verbal response competition.

Both Dyer (1973b) and Treisman and Fearnley (1969) have demonstrated that same-different matches between words and ink colors are slowed when the word is printed in an incongruent color. While these findings appear to reflect "sensory" interference with pictorial encoding, the simultaneous presentation of words and colors in both experiments makes it difficult to determine the direction and form of encoding actually used in the comparison. In addition, the same-different paradigm may not be the most appropriate task for inferring at what stage of encoding the interference occurs, since "same" and "different" judgments may themselves involve different levels of processing (Bindra, Donderi, \& Nishisato, 1968). The present study was therefore designed to extend the findings of Dyer (1973b) and Treisman and Fearnley (1969) by using a search task requiring forced-choice matches between sequentially presented words and color patches.

The visual search for ink colors, in which only "positive" stimulus instances are specified, would appear to involve rapid comparisons between sensory input and pictorial (i.e., nonlinguistic) internal representations. For example, Uleman and Reeves 
(1971) have shown that scanning for instances of a single ink color is no slower when the colors form incongruent words as when they form nonsense configurations, indicating that search is a visual "within-analyzer" task.

In the present study, however, the target color to be "searched" was specified by displaying a printed color name prior to the display of a field containing two color patches. Subjects were required to manually indicate the position of the color named by the word. Experimental variables included the delay between the word and color and the "irrelevant" color combined with the word in the first field. A variety of previous research (Posner, Boise, Eichelman, \& Taylor, 1969; Reed, 1973; Tversky, 1969) suggests that in tasks requiring the matching of sequentially displayed stimuli presented in different forms, the interval between stimuli is used to transform the information from the first stimulus into a form suitable for a very rapid comparison with the second stimulus. Thus one would expect to observe the slowest matching latencies between words and colors when the delay interval was very brief (e.g., $20 \mathrm{msec}$ ) as opposed to when it was somewhat longer (e.g., $700 \mathrm{msec}$ ). More importantly, if the presence of an incongruent and irrelevant ink color combined with the word display tends to block or delay the transformation of the word into a form suitable for a visual comparison, one would expect to observe interference effects with brief delay intervals, but an attenuation of this interference with longer delays.

\section{EXPERIMENT I}

\section{Method}

Subjects. Four University of Nebraska students (three female and one male) were paid $\$ 12$ for four 1 -h sessions. All four subjects were right-handed and had normal color vision; three of the subjects wore glasses for acuity corrections and were allowed to wear them during the experiment.

Stimulus materials. Stimulus materials consisted of a set of six "word" cards containing color names and a set of two "color choice" cards containing a pair of color patches. The color words were either "RED" or "GREEN" printed in capital letters. approximately $.5 \mathrm{~cm}$ high, in red, green, or blank ink. All six possible combinations of ink color and word were used, so that each color word was written in a congruent color (e.g., "RED" in red ink), an incongruent color (e.g., "RED" in green ink), or in black ink. Approximate Munsell notations of the red and green inks were 5R 4/12 and SG 4/6. The word cards upon which the color words were centered were white and approximately $12.7 \times 17.8 \mathrm{~cm}$ in size.

The two "color choice" cards were $12.7 \times 17.8 \mathrm{~cm}$ white cards, each containing one red and one green color patch. These color patches were XXXXs approximately $.5 \mathrm{~cm}$ high and centered on points $4.4 \mathrm{~cm}$ to the right and left, respectively, of the geometric center of the card. In one card, the red patch appeared on the right and the green patch on the left; these positions were reversed on the other card.

Apparatus. Stimuli were displayed in a Scientific Prototype Model GB three-channel tachistoscope. The subjects were seated in front of the viewing hood, at a table containing a row of three telegraph keys affixed to a movable base. In order to reduce the travel time required in making a response, the buttons upon the left and right keys were enlarged so that they nearly touched the button of the center key. The center key was a "start" key which initiated the display sequence, while the left and right keys were response keys which stopped a Lafayette digital clock measuring the latencies and indicated the response choice on an Esterline Angus event recorder.

Procedure. Upon an oral signal from the experimenter, each experimental trial was initiated by the subject's pressing the start key. Prior to the depression of this start key, a blank field containing a small fixation dot in the center was present. With the depression of the start key, a word card containing a color name was presented for $100 \mathrm{msec}$. followed by a blank interval $(20,100$, 300 , or $700 \mathrm{msec}$, as described below). followed by a color choice card which remained present for about $2.0 \mathrm{sec}$. The subjects were instructed to respond "as rapidly as possible without making errors" after the onset of the color choice card by pressing the key with the right hand, which corresponded to the position of the ink color named by the color word. Thus, if the word "RED" appeared in the first field, and the color choice card with red XXXXs on the left then appeared, the subjects would respond correctly by pressing the left button. RTs were measured as the time in milliseconds from the onset of the color choice field to the depression of a response key. The experimenter recorded both times and errors; the subjects were notified if an error occurred, but no feedback about times was given.

Experimental variables. Four different delay intervals were used (20. 100.300. and $700 \mathrm{msec}$ ). These delays indicate the time between the off set of the word tield and the initiation of the color patch field.

Three different color-nord combinations were used. The color word shown in the first fieid was printed in black ink, a congruemt color ink (RED in red ink or GREEN in green ink), or an incongruent color ink (RED in green ink or GREEN in red ink). The complete crossing of the four levels of delay and three color-word combinations thus produced a total of 12 experimental conditions.

Order of stimulus presentation. Within each of the four experimental sessions, each subject was run in four blocks of 30 trials each. Within each of these four blocks of trials, the delay level was held constant. The order of the delay levels within a session was determined by a 4 by 4 Latin square, a row of which was assigned to each subject. The order of presenting these delay levels was reversed for each subject on alternate days. Within each block of 30 trials, each of the three color-word combinations occurred 10 times (5 times in which the word was RED and 5 times when it was GREEN). "Right" and "left" responses occurred equally often within each color-word combination. A different random sequence of stimuli was used for each subject and each block of 30 trials. The tirst experimental session was treated as a practice session. and only data from the last three sessions were included in analysis.

\section{Results and Discussion}

Mean RTs and standard errors for each subject are displayed in Table $1 .{ }^{1}$ The overall means for each color-word combination are plotted as a function of delay in Figure 1. Comparisons among the three color combinations at each level of delay demonstrated significant differences for the 20 -msec delay $[F(2,6)=$ $24.6, p<.01]$ and the 100 -msec delay $[F(2,6)=7.82$, $p<.025]$. No significant differences were noted at the 300 - or 700 -msec delays.

These data thus illustrate a considerable influence of the ink color of the word on the matching latency, provided the delay between the word and color is sufficiently brief. Comparisons between the black and incongruent combinations revealed significant dif- 
Table 1

Mean RTs in Milliseconds as a Function of Delay and Color-Word Combination in Experiment I

\begin{tabular}{|c|c|c|c|c|c|c|c|c|c|c|c|c|c|}
\hline \multirow{2}{*}{ 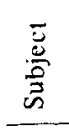 } & \multirow{2}{*}{ 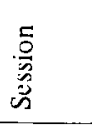 } & \multicolumn{3}{|c|}{ 20-Msec Delay } & \multicolumn{3}{|c|}{ 100-Msec Delay } & \multicolumn{3}{|c|}{ 300-Msec Delay } & \multicolumn{3}{|c|}{ 700-Msec Delay } \\
\hline & & $\begin{array}{l}\text { Con- } \\
\text { gruent }\end{array}$ & Black & $\begin{array}{l}\text { Incon- } \\
\text { gruent }\end{array}$ & $\begin{array}{c}\text { Con- } \\
\text { gruent }\end{array}$ & Black & $\begin{array}{l}\text { Incon- } \\
\text { gruent }\end{array}$ & $\begin{array}{c}\text { Con- } \\
\text { gruent }\end{array}$ & Black & $\begin{array}{l}\text { Incon- } \\
\text { gruent }\end{array}$ & $\begin{array}{l}\text { Con- } \\
\text { gruent }\end{array}$ & Black & $\begin{array}{l}\text { Incon- } \\
\text { gruent }\end{array}$ \\
\hline & 1 & $\begin{array}{r}417^{*} \\
(15.4)\end{array}$ & $\begin{array}{c}500 \\
(19.6)\end{array}$ & $\begin{array}{c}468 \\
(17.6)\end{array}$ & $\begin{array}{c}390 \\
(18.4)\end{array}$ & $\begin{array}{l}425 \\
(21.1)\end{array}$ & $\begin{array}{c}412 \\
(22.9)\end{array}$ & $\begin{array}{c}370 \\
(11.8)\end{array}$ & $\begin{array}{l}466 \\
(36.1)\end{array}$ & $\begin{array}{c}400 \\
(19.4)\end{array}$ & $\begin{array}{c}438 \\
(15.6)\end{array}$ & $\begin{array}{c}423 \\
(17.5)\end{array}$ & $\begin{array}{c}436 \\
(30.9)\end{array}$ \\
\hline \multirow[t]{2}{*}{ C.K. } & 2 & $\begin{array}{c}392 \\
(43.9)\end{array}$ & $\begin{array}{c}425 \\
(64.1)\end{array}$ & $\begin{array}{l}445 \\
(71.1)\end{array}$ & $\begin{array}{c}426 \\
(28.3)\end{array}$ & $\begin{array}{c}373 \\
(14.6)\end{array}$ & $\begin{array}{c}400 \\
(18.7)\end{array}$ & $\begin{array}{c}399 \\
(7.9)\end{array}$ & $\begin{array}{c}406 \\
(13.1)\end{array}$ & $\begin{array}{c}403 \\
(16.1)\end{array}$ & $\begin{array}{c}411 \\
(17.4)\end{array}$ & $\begin{array}{c}386 \\
(14.0)\end{array}$ & $\begin{array}{c}403 \\
(18.8)\end{array}$ \\
\hline & 3 & $\begin{array}{c}348 \\
(8.9)\end{array}$ & $\begin{array}{c}392 \\
(22.1)\end{array}$ & $\begin{array}{c}419 \\
(21.8)\end{array}$ & $\begin{array}{c}336 \\
(16.9)\end{array}$ & $\begin{array}{c}345 \\
(10.7)\end{array}$ & $\begin{array}{c}369 \\
(24.6)\end{array}$ & $\begin{array}{c}383 \\
(14.8)\end{array}$ & $\begin{array}{c}361 \\
(10.7)\end{array}$ & $\begin{array}{c}383 \\
(15.4)\end{array}$ & $\begin{array}{c}385 \\
(16.3)\end{array}$ & $\begin{array}{c}373 \\
(15.2)\end{array}$ & $\begin{array}{c}359 \\
(12.3)\end{array}$ \\
\hline \multirow[t]{2}{*}{ Mean } & & 386 & 439 & 444 & 384 & 381 & 394 & 384 & 411 & 395 & 411 & 394 & 399 \\
\hline & 1 & $\begin{array}{c}393 \\
(20.6)\end{array}$ & $\begin{array}{c}488 \\
(26.1)\end{array}$ & $\begin{array}{c}479 \\
(19.8)\end{array}$ & $\begin{array}{c}389 \\
(12.7)\end{array}$ & $\begin{array}{c}386 \\
(11.4)\end{array}$ & $\begin{array}{c}416 \\
(21.9)\end{array}$ & $\begin{array}{c}332 \\
(10.4)\end{array}$ & $\begin{array}{c}364 \\
(16.5)\end{array}$ & $\begin{array}{c}357 \\
(14.2)\end{array}$ & $\begin{array}{c}360 \\
(9.9)\end{array}$ & $\begin{array}{c}363 \\
(15.0)\end{array}$ & $\begin{array}{c}366 \\
(14.6)\end{array}$ \\
\hline \multirow[t]{2}{*}{ S.M. } & 2 & $\begin{array}{c}358 \\
(9.6)\end{array}$ & $\begin{array}{c}396 \\
(18.5)\end{array}$ & $\begin{array}{c}447 \\
(23.7)\end{array}$ & $\begin{array}{c}332 \\
(18.5)\end{array}$ & $\begin{array}{c}363 \\
(9.1)\end{array}$ & $\begin{array}{l}410 \\
(34.2)\end{array}$ & $\begin{array}{c}341 \\
(13.8)\end{array}$ & $\begin{array}{c}381 \\
(19.1)\end{array}$ & $\begin{array}{c}402 \\
(33.0)\end{array}$ & $\begin{array}{l}380 \\
(25.0)\end{array}$ & $\begin{array}{c}390 \\
(29.5)\end{array}$ & $\begin{array}{c}410 \\
(39.4)\end{array}$ \\
\hline & 3 & $\begin{array}{c}362 \\
(12.3)\end{array}$ & $\begin{array}{c}390 \\
(21.6)\end{array}$ & $\begin{array}{c}512 \\
(60.3)\end{array}$ & $\begin{array}{c}436 \\
(19.5)\end{array}$ & $\begin{array}{c}525 \\
(49.1)\end{array}$ & $\begin{array}{l}557 \\
(52.0)\end{array}$ & $\begin{array}{c}406 \\
(20.7)\end{array}$ & $\begin{array}{c}446 \\
(36.4)\end{array}$ & $\begin{array}{c}404 \\
(19.6)\end{array}$ & $\begin{array}{c}464 \\
(57.9)\end{array}$ & $\begin{array}{c}427 \\
(14.4)\end{array}$ & $\begin{array}{c}350 \\
(25.9)\end{array}$ \\
\hline \multirow[t]{2}{*}{ Mean } & & 371 & 425 & 479 & 386 & 425 & 461 & 360 & 397 & 388 & 401 & 393 & 375 \\
\hline & 1 & $\begin{array}{l}416 \\
(38.3)\end{array}$ & $\begin{array}{l}453 \\
(31.6)\end{array}$ & $\begin{array}{c}463 \\
(28.3)\end{array}$ & $\begin{array}{c}266 \\
(23.0)\end{array}$ & $\begin{array}{c}329 \\
(17.6)\end{array}$ & $\begin{array}{c}340 \\
(24.0)\end{array}$ & $\begin{array}{c}297 \\
(11.2)\end{array}$ & $\begin{array}{c}293 \\
(9.5)\end{array}$ & $\begin{array}{c}327 \\
(9.4)\end{array}$ & $\begin{array}{c}323 \\
(10.9)\end{array}$ & $\begin{array}{c}329 \\
(21.3)\end{array}$ & $\begin{array}{c}332 \\
(11.5)\end{array}$ \\
\hline \multirow[t]{2}{*}{ R.C. } & 2 & $\begin{array}{c}318 \\
(19.6)\end{array}$ & $\begin{array}{c}310 \\
(16.3)\end{array}$ & $\begin{array}{c}438 \\
(56.3)\end{array}$ & $\begin{array}{c}307 \\
(16.7)\end{array}$ & $\begin{array}{c}296 \\
(13.7)\end{array}$ & $\begin{array}{c}411 \\
(47.5)\end{array}$ & $\begin{array}{c}.99 \\
(11.8)\end{array}$ & $\begin{array}{l}280 \\
(8.9)\end{array}$ & $\begin{array}{c}322 \\
(16.5)\end{array}$ & $\begin{array}{c}292 \\
(12.3)\end{array}$ & $\begin{array}{c}285 \\
(12.5)\end{array}$ & $\begin{array}{c}307 \\
(10.4)\end{array}$ \\
\hline & 3 & $\begin{array}{c}298 \\
(16.5)\end{array}$ & $\begin{array}{c}347 \\
(18.0)\end{array}$ & $\begin{array}{c}382 \\
(31.4)\end{array}$ & $\begin{array}{c}318 \\
(5.0)\end{array}$ & $\begin{array}{c}319 \\
(11.7)\end{array}$ & $\begin{array}{c}397 \\
(29.9)\end{array}$ & $\begin{array}{c}301 \\
(9.6)\end{array}$ & $\begin{array}{c}292 \\
(10.2)\end{array}$ & $\begin{array}{c}313 \\
(11.6)\end{array}$ & $\begin{array}{c}285 \\
(17.5)\end{array}$ & $\begin{array}{c}283 \\
(14.4)\end{array}$ & $\begin{array}{c}294 \\
(13.8)\end{array}$ \\
\hline \multirow[t]{2}{*}{ Mean } & & 344 & 370 & 428 & 297 & 315 & 383 & 299 & 288 & 321 & 300 & 299 & 311 \\
\hline & 1 & $\begin{array}{c}438 \\
(11.6)\end{array}$ & $\begin{array}{c}439 \\
(18.9)\end{array}$ & $\begin{array}{c}509 \\
(33.0)\end{array}$ & $\begin{array}{c}456 \\
(41.5)\end{array}$ & $\begin{array}{c}446 \\
(32.3)\end{array}$ & $\begin{array}{l}559 \\
(41.2)\end{array}$ & $\begin{array}{c}382 \\
(37.8)\end{array}$ & $\begin{array}{c}385 \\
(29.9)\end{array}$ & $\begin{array}{c}369 \\
(19.1)\end{array}$ & $\begin{array}{c}359 \\
(24.6)\end{array}$ & $\begin{array}{c}355 \\
(23.8)\end{array}$ & $\begin{array}{c}378 \\
(20.5)\end{array}$ \\
\hline \multirow[t]{2}{*}{ G.N. } & 2 & $\begin{array}{c}374 \\
(19.5)\end{array}$ & $\begin{array}{c}376 \\
(13.9)\end{array}$ & $\begin{array}{c}459 \\
(30.3)\end{array}$ & $\begin{array}{c}380 \\
(18.6)\end{array}$ & $\begin{array}{c}348 \\
(19.9)\end{array}$ & $\begin{array}{c}388 \\
(20.5)\end{array}$ & $\begin{array}{c}402 \\
(37.9)\end{array}$ & $\begin{array}{c}365 \\
(17.9)\end{array}$ & $\begin{array}{c}365 \\
(11.9)\end{array}$ & $\begin{array}{c}370 \\
(18.4)\end{array}$ & $\begin{array}{c}354 \\
(10.7)\end{array}$ & $\begin{array}{c}356 \\
(9.7)\end{array}$ \\
\hline & 3 & $\begin{array}{c}385 \\
(13.2)\end{array}$ & $\begin{array}{c}418 \\
(9.1)\end{array}$ & $\begin{array}{c}483 \\
(23.9)\end{array}$ & $\begin{array}{c}389 \\
(37.8)\end{array}$ & $\begin{array}{c}354 \\
(9.6)\end{array}$ & $\begin{array}{c}429 \\
(23.7)\end{array}$ & $\begin{array}{c}319 \\
(10.6)\end{array}$ & $\begin{array}{c}330 \\
(13.9)\end{array}$ & $\begin{array}{c}393 \\
(36.5)\end{array}$ & $\begin{array}{c}395 \\
(28.1)\end{array}$ & $\begin{array}{c}346 \\
(12.3)\end{array}$ & $\begin{array}{c}370 \\
(13.8)\end{array}$ \\
\hline $\begin{array}{l}\text { Mean } \\
\text { Grand }\end{array}$ & Mean & $\begin{array}{l}399 \\
375\end{array}$ & $\begin{array}{l}411 \\
411\end{array}$ & $\begin{array}{l}484 \\
459\end{array}$ & $\begin{array}{l}408 \\
369\end{array}$ & $\begin{array}{l}383 \\
376\end{array}$ & $\begin{array}{l}459 \\
424\end{array}$ & $\begin{array}{l}368 \\
353\end{array}$ & $\begin{array}{l}360 \\
364\end{array}$ & $\begin{array}{l}376 \\
370\end{array}$ & $\begin{array}{l}375 \\
372\end{array}$ & $\begin{array}{l}352 \\
360\end{array}$ & $\begin{array}{l}368 \\
363\end{array}$ \\
\hline
\end{tabular}

* Main cell entries are mean RTs in milliseconds based on 10 trials; standard errors of those means are shown in parentheses.

ferences at both the 20 - and the 100 -msec delays $[F(1.6)=15.8, p<.01 ; F(1.6)=10.0, p<.025]$. Evidence that the congruently colored words produced slightly faster matching latencies than the black words is limited to the 20 -msec delay $[F(1,6)=$ $9.1, \mathrm{p}<.025]$; in fact, $2 / 4$ subjects had faster overall matching latencies to the black words than to the congruently colored words at the $100-\mathrm{msec}$ delay. Thus the preponderance of the influence of the color-word combination would appear to be an interference effect in which incongruent ink colors produce larger word-color matching latencies than either the black or the congruent combinations.

A further breakdown of the data from the $20-\mathrm{msec}$. delay is shown in Figure 2, which reveals that the same ordering of matching latencies (congruent RTs $<$ black RTs < incongruent RTs) occurred whether the word was RED or GREEN. Analysis of variance of these data revealed no significant interaction between the color-word combination and which word was presented $(F<1)$.

These data from Experiment I are thus consistent with a selective attention model in which the process

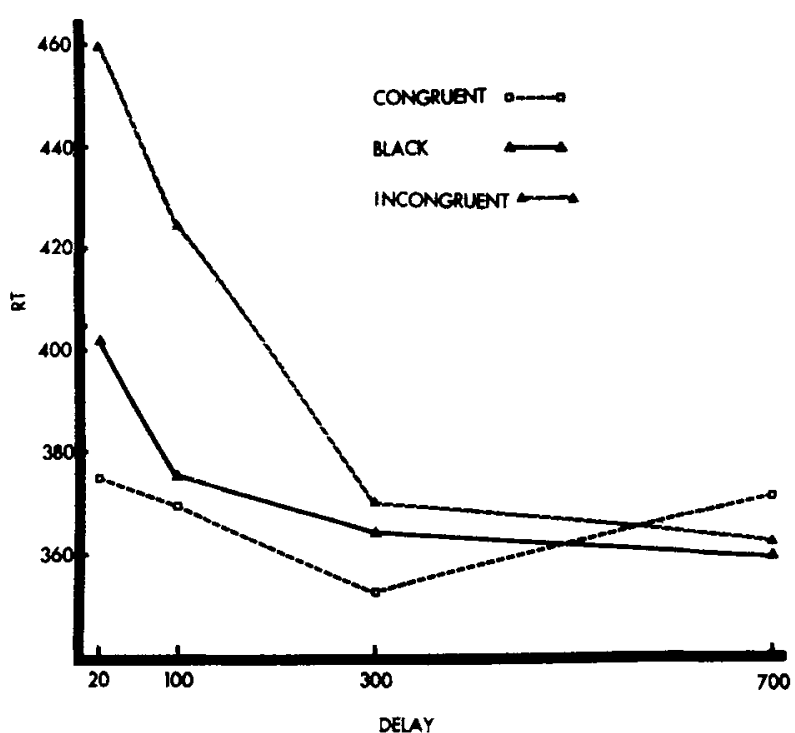

Figure 1. Mean RT in milliseconds for all subjects and conditions in Experiment $I$, plotted as a function of delay and color-word combinations. 


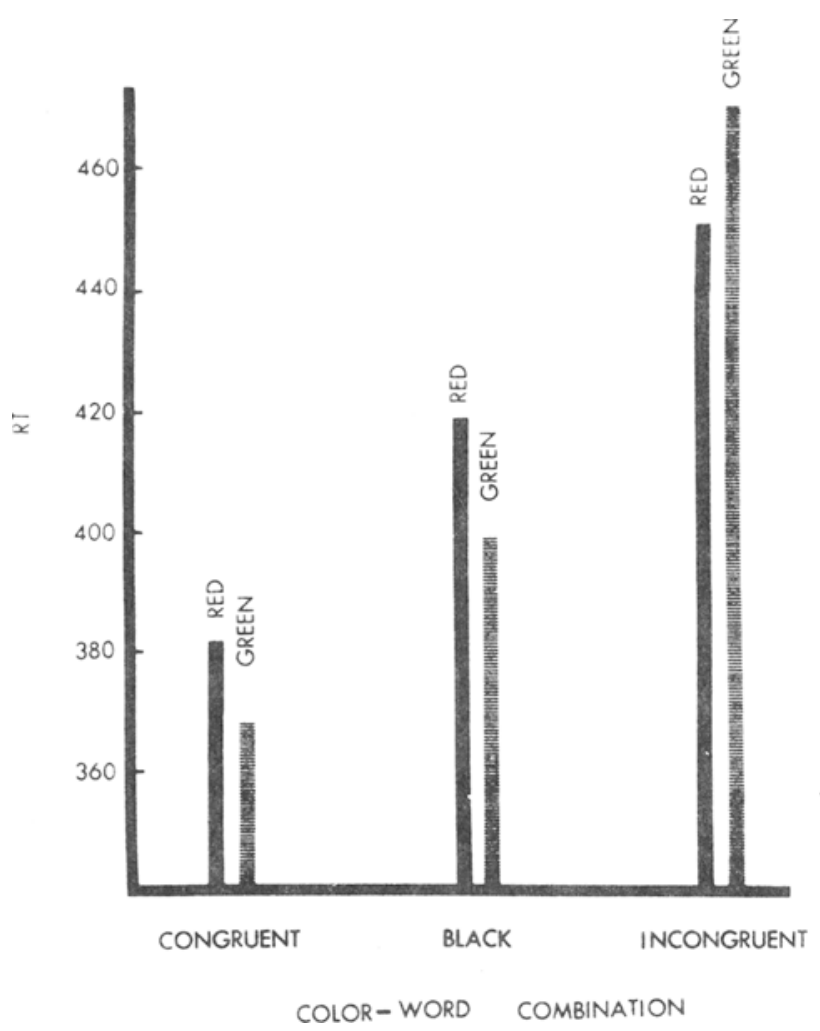

Figure 2. Mean RT in milliseconds for the three color-word combinations at the 20 -msec delay, plotted separately for trials in which the word was RED and trials on which the word was GREEN.

of pictorially encoding the word to perform a rapid "visual" match with the subsequently presented color patch is disrupted by failure to gate the irrelevant ink color of the word. Substantial interference occurs when the word-color delay is brief, but this effect disappears with longer delays.

The slightly faster RTs observed for the congruent color-word combinations than for the black combinations of the $20-\mathrm{msec}$ delay raises the issue of whether facilitation from congruent linguistic and sensory stimulus components was taking place. Although Dyer (1973b) has argued that such findings do represent facilitation, that term is more typically used in describing situations in which two or more correlated stimulus dimensions produce faster discrimination than in conditions in which one of the dimensions is held constant. Because color-word combinations were mixed within a block of trials in the present experiment, one might also argue that the black ink was processed as having some "degree of incongruency" with the colors named by the word, particularly since the red and green inks differed in brightness and saturation as well as hue. This "degree of incongruency" interpretation suggested a second experiment, in which the word was combined with a wider range of irrelevant colors.

\section{EXPERIMENT II}

Subjects. Twenty-four University of Nebraska Undergraduates soluntered as subjects as a means of fulfilling a course requirement. All subjects had normal color vision, and those who work glasses for acuity corrections wore them during the experiment. The subjects were run in groups of three, in a single session lasting about $2 \mathrm{~h}$.

Stimulus materials. As in Experiment 1. each trial consisted of the sequential presentation of a "word" field and a "color choice" tield. The word stimuli consisted of $35-\mathrm{mm}$ slides containing the lowercase words "red" or "green" that were printed on a clear transparent film which was then overlayed with a colored transparent acetate gel. When projected on a viewing screen, the letters appeared in black. approxinuately $0.4 \mathrm{~cm}$ in height (for the rs. es. and ns) and surrounded by a colored background field approxinately $1.0 \times 1.5 \mathrm{~m}$. There were tive alternative background colors (red, purple. blue, blue-green, and green) which had approximate Munsell hue levels of $5 R, 10 \mathrm{P}, 5 \mathrm{~B}, 4 \mathrm{BG}$, and $2.5 \mathrm{G}$, respectively. The combination of these tive background colors with the two words produced 10 different word tield stimuli.

The color choice field was produced by slides containing both red and green gel, overlayed with the same type of transparent clear gel used to produce the word stimuli. These slides produced a $1.5 \times 1.0 \mathrm{~m}$ field, which on half the trials was uniformly red $(5 \mathrm{R})$ in the right half of the field and uniform!y green $(2.5 \mathrm{G})$ in the left halt of the field. On the remaining trials. these positions were reversed.

Task and Apparatus. Stimuli were displayed by means of two Carousel projectors combined with Lafayette tachistoscopic shutters. The operation of these shutters and the advancement of the slide trays was controlled by a bank of Hunter timers. Each stimulus sequence was initiated by the experimenter. who was seated in a control booth at the rear of the experimental room.

The subjects were seated at three experimental booths located at a viewing distance of approximately $5 \mathrm{~m}$ from the projection screen. Each booth contained a set of two response buttons. one each for the left and right hands. The set of buttons in each booth operated one of three sets of response indicator lights and stopped one of three Hunter Klockounters located in the control booth. The experimental room was dimly lit: the only illumination was provided by a 15-W incandescent lamp located in the control booth which permitted the experimenter to record data manually.

Prior to the initiation of each stimulus sequence. the viewing screen was not illuminated, but was clearly visible with the dim room illumination. Following an oral "ready" signal, the experimenter initiated each trial by pressing a control switch. This initiated the display of the word field for $100 \mathrm{msec}$, followed by a delay interval during which the screen was not illuminated, followed by the color choice ficld, which remained on for $2.0 \mathrm{sec}$. For 12 subjects, the delay between the oftset of the word field and the onset of the color choice field was $20 \mathrm{msec}$, while for the remaining 12 subjects the delay was $500 \mathrm{msec}$. The task was essentially identical to that of Experiment I; the subjects were instructed to respond "as rapidly as possible without making errors" after the onset of the color choice lield, by pressing the button which corresponded to the position on the field of the color named by the previously displayed word. However, the responses were made with two hands rather than with a single hand as in Experiment $I$.

Fach group of three subjects received five blocks of 52 trials each during the session. A 5 -min break was given between blocks. The initial block of trials was considered practice and was omitted from analysis. In the remaining four blocks of trials. the initial two trials were also omitted from analysis. Within the remaining 50 trials. each of the 10 possible color word combinations occurred five times-thus providing a total of 20 possible ${ }^{2}$ stimulus presentations for each combination of word and background color during an experimental session. Of these, 10 required "right" responses and 10 required "left" responses. Four different stimulus orders were used; cach order was used for one group of three subjects for whom the delat between the word and choice tields was 20 msees. and for one group of three subjects for whom the delay was 500 msec. These orders were restricted so that no identical combination of background color and word could occur on successive trials. 
Table 2

Mean RTs in Milliseconds for Each Combination of Word and Background Color in Experiment II (Delay = $20 \mathrm{Msec})$

\begin{tabular}{|c|c|c|c|c|c|c|c|c|c|c|}
\hline \multirow[b]{2}{*}{ Subject } & \multicolumn{5}{|c|}{ Word = "Red" } & \multicolumn{5}{|c|}{ Word = "Green" } \\
\hline & $\mathrm{R}$ & $\mathbf{P}$ & $\mathrm{B}$ & BG & $\mathrm{G}$ & $\mathbf{R}$ & $\mathbf{P}$ & B & BG & G \\
\hline 1 & $\begin{array}{l}426 \\
(13.7)^{*}\end{array}$ & $\begin{array}{c}542 \\
(22.5)\end{array}$ & $\begin{array}{c}566 \\
(24.2)\end{array}$ & $\begin{array}{c}581 \\
(37.4)\end{array}$ & $\begin{array}{c}557 \\
(20.7)\end{array}$ & $\begin{array}{c}540 \\
(20.6)\end{array}$ & $\begin{array}{c}536 \\
(35.0)\end{array}$ & $\begin{array}{c}448 \\
(27.1)\end{array}$ & $\begin{array}{c}459 \\
(23.1)\end{array}$ & $\begin{array}{c}435 \\
(21.2)\end{array}$ \\
\hline 2 & $\begin{array}{c}473 \\
(25.4)\end{array}$ & $\begin{array}{c}540 \\
(25.8)\end{array}$ & $\begin{array}{c}562 \\
(36.6)\end{array}$ & $\begin{array}{l}524 \\
(21.1)\end{array}$ & $\begin{array}{c}481 \\
(22.7)\end{array}$ & $\begin{array}{c}606 \\
(48.7)\end{array}$ & $\begin{array}{c}429 \\
(18.7)\end{array}$ & $\begin{array}{c}459 \\
(18.9)\end{array}$ & $\begin{array}{c}505 \\
(26.5)\end{array}$ & $\begin{array}{c}498 \\
(27.2)\end{array}$ \\
\hline 3 & $\begin{array}{c}346 \\
(14.7)\end{array}$ & $\begin{array}{c}411 \\
(17.9)\end{array}$ & $\begin{array}{c}438 \\
(38.2)\end{array}$ & $\begin{array}{c}490 \\
(46.4)\end{array}$ & $\begin{array}{c}471 \\
(47.7)\end{array}$ & $\begin{array}{c}453 \\
(19.7)\end{array}$ & $\begin{array}{c}443 \\
(22.5)\end{array}$ & $\begin{array}{c}375 \\
(15.5)\end{array}$ & $\begin{array}{c}411 \\
(14.7)\end{array}$ & $\begin{array}{c}400 \\
(17.7)\end{array}$ \\
\hline 4 & $\begin{array}{c}393 \\
(11.5)\end{array}$ & $\begin{array}{c}431 \\
(12.3)\end{array}$ & $\begin{array}{c}528 \\
(31.6)\end{array}$ & $\begin{array}{c}543 \\
(51.1)\end{array}$ & $\begin{array}{c}515 \\
(30.1)\end{array}$ & $\begin{array}{c}524 \\
(31.8)\end{array}$ & $\begin{array}{c}418 \\
(15.8)\end{array}$ & $\begin{array}{c}385 \\
(13.7)\end{array}$ & $\begin{array}{c}402 \\
(13.8)\end{array}$ & $\begin{array}{c}389 \\
(18.1)\end{array}$ \\
\hline 5 & $\begin{array}{c}308 \\
(13.1)\end{array}$ & $\begin{array}{c}342 \\
(11.2)\end{array}$ & $\begin{array}{c}385 \\
(14.2)\end{array}$ & $\begin{array}{c}389 \\
(17.4)\end{array}$ & $\begin{array}{c}398 \\
(18.7)\end{array}$ & $\begin{array}{c}375 \\
(17.7)\end{array}$ & $\begin{array}{c}366 \\
(17.8)\end{array}$ & $\begin{array}{c}303 \\
(13.6)\end{array}$ & $\begin{array}{c}316 \\
(7.6)\end{array}$ & $\begin{array}{c}294 \\
(10.6)\end{array}$ \\
\hline 6 & $\begin{array}{c}433 \\
(17.0)\end{array}$ & $\begin{array}{c}463 \\
(18.1)\end{array}$ & $\begin{array}{c}560 \\
(42.7)\end{array}$ & $\begin{array}{c}561 \\
(26.8)\end{array}$ & $\begin{array}{c}520 \\
(29.1)\end{array}$ & $\begin{array}{c}641 \\
(45.8)\end{array}$ & $\begin{array}{c}508 \\
(33.1)\end{array}$ & $\begin{array}{c}408 \\
(16.0)\end{array}$ & $\begin{array}{c}434 \\
(13.4)\end{array}$ & $\begin{array}{c}426 \\
(14.9)\end{array}$ \\
\hline 7 & $\begin{array}{c}369 \\
(14.5)\end{array}$ & $\begin{array}{c}425 \\
(16.5)\end{array}$ & $\begin{array}{c}526 \\
(28.3)\end{array}$ & $\begin{array}{c}539 \\
(43.2)\end{array}$ & $\begin{array}{c}513 \\
(33.9)\end{array}$ & $\begin{array}{c}693 \\
(52.1)\end{array}$ & $\begin{array}{c}461 \\
(29.4)\end{array}$ & $\begin{array}{c}386 \\
(19.7)\end{array}$ & $\begin{array}{c}380 \\
(12.2)\end{array}$ & $\begin{array}{c}410 \\
(19.1)\end{array}$ \\
\hline 8 & $\begin{array}{c}371 \\
(8.4)\end{array}$ & $\begin{array}{c}437 \\
(26.9)\end{array}$ & $\begin{array}{c}462 \\
(15.4)\end{array}$ & $\begin{array}{c}506 \\
(30.7)\end{array}$ & $\begin{array}{c}455 \\
(28.6)\end{array}$ & $\begin{array}{c}624 \\
(41.1)\end{array}$ & $\begin{array}{c}457 \\
(16.1)\end{array}$ & $\begin{array}{c}429 \\
(15.6)\end{array}$ & $\begin{array}{c}410 \\
(16.0)\end{array}$ & $\begin{array}{c}436 \\
(21.8)\end{array}$ \\
\hline 9 & $\begin{array}{c}488 \\
(11.4)\end{array}$ & $\begin{array}{c}607 \\
(42.3)\end{array}$ & $\begin{array}{l}548 \\
(30.8)\end{array}$ & $\begin{array}{l}527 \\
(25.1)\end{array}$ & $\begin{array}{c}557 \\
(30.2)\end{array}$ & $\begin{array}{c}654 \\
(27.7)\end{array}$ & $\begin{array}{c}536 \\
(18.0)\end{array}$ & $\begin{array}{c}553 \\
(22.4)\end{array}$ & $\begin{array}{c}509 \\
(13.5)\end{array}$ & $\begin{array}{c}513 \\
(15.1)\end{array}$ \\
\hline 10 & $\begin{array}{c}443 \\
(31.8)\end{array}$ & $\begin{array}{c}444 \\
(18.7)\end{array}$ & $\begin{array}{c}537 \\
(31.9)\end{array}$ & $\begin{array}{c}534 \\
(26.3)\end{array}$ & $\begin{array}{c}517 \\
(21.6)\end{array}$ & $\begin{array}{l}525 \\
(28.0)\end{array}$ & $\begin{array}{c}446 \\
(16.3)\end{array}$ & $\begin{array}{c}451 \\
(29.0)\end{array}$ & $\begin{array}{c}440 \\
(30.3)\end{array}$ & $\begin{array}{c}446 \\
(31.4)\end{array}$ \\
\hline 11 & $\begin{array}{c}370 \\
(20.1)\end{array}$ & $\begin{array}{c}419 \\
(26.9)\end{array}$ & $\begin{array}{c}504 \\
(27.4)\end{array}$ & $\begin{array}{c}442 \\
(16.3)\end{array}$ & $\begin{array}{c}437 \\
(28.5)\end{array}$ & $\begin{array}{c}497 \\
(33.8)\end{array}$ & $\begin{array}{c}388 \\
(13.7)\end{array}$ & $\begin{array}{c}348 \\
(15.0)\end{array}$ & $\begin{array}{c}363 \\
(16.6)\end{array}$ & $\begin{array}{c}378 \\
(14.5)\end{array}$ \\
\hline 12 & $\begin{array}{c}388 \\
(17.7)\end{array}$ & $\begin{array}{c}449 \\
(34.8)\end{array}$ & $\begin{array}{c}515 \\
(37.1)\end{array}$ & $\begin{array}{c}508 \\
(36.6)\end{array}$ & $\begin{array}{c}504 \\
(48.7)\end{array}$ & $\begin{array}{c}566 \\
(54.3)\end{array}$ & $\begin{array}{c}436 \\
(14.1)\end{array}$ & $\begin{array}{c}360 \\
(16.9)\end{array}$ & $\begin{array}{c}386 \\
(13.9)\end{array}$ & $\begin{array}{c}361 \\
(13.9)\end{array}$ \\
\hline Mean & 401 & 459 & 511 & 512 & 494 & 558 & 452 & 409 & 418 & 416 \\
\hline
\end{tabular}

*SEs are shown in parentheses.

\section{Results and Discussion}

Mean RTs and standard errors for each subject are displayed in Tables 2 and 3, while the overall mean RT's are plotted as a function of background color in Figures 3 and $4 .{ }^{3}$ For the subjects for whom the delay wils 20 msec, the background color produced a large and highly significant influence on the matching latency, both when the word was "red" $[F(4,44)=$ 33.6. $\mathrm{p}<.001]$ and when the word was "green" $[F(4,44)=33.2, p<.001]$. However, this effect is substantially attenuated for the 500 -msec-delay group. Figure 4 indicates that matching latencies were essentially constant across background colors on trials in which the word was "red" $[F(4,44)=1.2$, $p>.10]$, although a significant effect of background color was still noted for trials in which the word was "green" $[F(4,44)=9.3 . p<.01]$. Figure 4 suggests that the preponderance of this effect is due to the longer matching latencies produced by the red background when the word was "green." These tindings are thus consistent with those in Experiment I, demonstrating a large "reverse Stroop" interference effect with word-to-color matching when the interval between the word and color is brief ( $20 \mathrm{msec}$ ) but a substantial reduction of this interference when this interval is several hundred milliseconds. In addition, this second experiment has demonstrated that this interference effect can be produced by a color field which surrounds the word as well as by the ink color of the word itself.

Figure 3 suggests that for the $20-\mathrm{msec}$ delay there is a strong relationship between the colorimetric discrepancy between the background and the "relevant" color named by the word and the matching latency. Those background colors which produce the shortest matching latencies when the word is "red" produce the longest latencies when the word is "green," and vice versa. Individual comparisons between the RTs for the different combinations of background color and word reveal that when the word was "red," the purple background produced significantly longer RTs than the red background $[F(1,44)=26.2, p<.01]$ and the blue background produced longer RTs than the purple background $[F(1,44)=20.6, p<.01]$. When the word was "green," the red background produced significantly longer RTs than the purple background $[F(1,44)=$ 48.2. $\mathrm{p}<.01]$ and the purple background produced significantly longer latencies than the blue background $[F(1,44)=7.82, p<.01]$. There appears to have been little differential effect of the blue, blue-green, or green backgrounds; these hues produced approximately uniformly long RTs when the word was "red" and uniformly short RTs when the 
Table 3

Mean RTs in Milliseconds for Each Combination of Word and Background Color in Experiment II (Delay = 500 Msec)*

\begin{tabular}{|c|c|c|c|c|c|c|c|c|c|c|}
\hline \multirow[b]{2}{*}{ Subject } & \multicolumn{5}{|c|}{ Word = "Red" } & \multicolumn{5}{|c|}{ Word = "Green" } \\
\hline & $\mathbf{R}$ & $\mathbf{P}$ & B & BG & G & $\mathbf{R}$ & $\mathbf{P}$ & B & BG & $\mathrm{G}$ \\
\hline 1 & $\begin{array}{c}269 \\
(10.4)\end{array}$ & $\begin{array}{c}253 \\
(15.5)\end{array}$ & $\begin{array}{c}261 \\
(8.7)\end{array}$ & $\begin{array}{c}283 \\
(8.5)\end{array}$ & $\begin{array}{c}273 \\
(11.5)\end{array}$ & $\begin{array}{c}279 \\
(8.8)\end{array}$ & $\begin{array}{c}306 \\
(13.0)\end{array}$ & $\begin{array}{c}285 \\
(9.0)\end{array}$ & $\begin{array}{c}280 \\
(8.5)\end{array}$ & $\begin{array}{c}275 \\
(9.4)\end{array}$ \\
\hline 2 & $\begin{array}{c}281 \\
(9.8)\end{array}$ & $\begin{array}{c}301 \\
(13.8)\end{array}$ & $\begin{array}{c}288 \\
(15.3)\end{array}$ & $\begin{array}{c}280 \\
(12.7)\end{array}$ & $\begin{array}{c}278 \\
(14.9)\end{array}$ & $\begin{array}{c}318 \\
(17.4)\end{array}$ & $\begin{array}{c}276 \\
(12.9)\end{array}$ & $\begin{array}{c}300 \\
(8.6)\end{array}$ & $\begin{array}{c}305 \\
(12.6)\end{array}$ & $\begin{array}{c}314 \\
(19.6)\end{array}$ \\
\hline 3 & $\begin{array}{c}225 \\
(9.1)\end{array}$ & $\begin{array}{c}236 \\
(7.5)\end{array}$ & $\begin{array}{c}244 \\
(5.7)\end{array}$ & $\begin{array}{c}253 \\
(8.9)\end{array}$ & $\begin{array}{c}257 \\
(15.2)\end{array}$ & $\begin{array}{c}257 \\
(5.9)\end{array}$ & $\begin{array}{c}247 \\
(5.2)\end{array}$ & $\begin{array}{c}256 \\
(7.1)\end{array}$ & $\begin{array}{c}246 \\
(10.5)\end{array}$ & $\begin{array}{l}266 \\
(16.6)\end{array}$ \\
\hline 4 & $\begin{array}{l}293 \\
(14.9)\end{array}$ & $\begin{array}{c}318 \\
(20.2)\end{array}$ & $\begin{array}{c}306 \\
(14.4)\end{array}$ & $\begin{array}{c}311 \\
(11.7)\end{array}$ & $\begin{array}{c}329 \\
(17.9)\end{array}$ & $\begin{array}{c}422 \\
(34.2)\end{array}$ & $\begin{array}{c}310 \\
(12.5)\end{array}$ & $\begin{array}{c}324 \\
(12.1)\end{array}$ & $\begin{array}{c}341 \\
(15.0)\end{array}$ & $\begin{array}{c}352 \\
(11.8)\end{array}$ \\
\hline 5 & $\begin{array}{c}317 \\
(17.4)\end{array}$ & $\begin{array}{c}316 \\
(11.2)\end{array}$ & $\begin{array}{c}314 \\
(8.9)\end{array}$ & $\begin{array}{c}301 \\
(11.0)\end{array}$ & $\begin{array}{c}319 \\
(11.9)\end{array}$ & $\begin{array}{c}313 \\
(9.9)\end{array}$ & $\begin{array}{c}305 \\
(12.9)\end{array}$ & $\begin{array}{c}304 \\
(8.3)\end{array}$ & $\begin{array}{c}332 \\
(11.0)\end{array}$ & $\begin{array}{c}304 \\
(8.9)\end{array}$ \\
\hline 6 & $\begin{array}{c}261 \\
(9.3)\end{array}$ & $\begin{array}{c}273 \\
(12.8)\end{array}$ & $\begin{array}{c}328 \\
(31.8)\end{array}$ & $\begin{array}{l}278 \\
(14.5)\end{array}$ & $\begin{array}{c}307 \\
(15.3)\end{array}$ & $\begin{array}{c}340 \\
(15.6)\end{array}$ & $\begin{array}{c}264 \\
(\quad 6.9)\end{array}$ & $\begin{array}{c}288 \\
(12.8)\end{array}$ & $\begin{array}{c}288 \\
(10.4)\end{array}$ & $\begin{array}{c}272 \\
(31.2)\end{array}$ \\
\hline 7 & $\begin{array}{c}266 \\
(13.8)\end{array}$ & $\begin{array}{c}295 \\
(18.0)\end{array}$ & $\begin{array}{c}337 \\
(25.8)\end{array}$ & $\begin{array}{c}302 \\
(17.4)\end{array}$ & $\begin{array}{c}339 \\
(31.7)\end{array}$ & $\begin{array}{c}361 \\
(33.8)\end{array}$ & $\begin{array}{c}292 \\
(17.6)\end{array}$ & $\begin{array}{c}317 \\
(13.3)\end{array}$ & $\begin{array}{c}280 \\
(14.7)\end{array}$ & $\begin{array}{c}279 \\
(12.0)\end{array}$ \\
\hline 8 & $\begin{array}{c}325 \\
(29.8)\end{array}$ & $\begin{array}{c}335 \\
(21.6)\end{array}$ & $\begin{array}{c}300 \\
(11.6)\end{array}$ & $\begin{array}{c}317 \\
(12.3)\end{array}$ & $\begin{array}{c}311 \\
(15.0)\end{array}$ & $\begin{array}{c}352 \\
(13.0)\end{array}$ & $\begin{array}{c}331 \\
(15.6)\end{array}$ & $\begin{array}{c}347 \\
(13.1)\end{array}$ & $\begin{array}{c}330 \\
(14.0)\end{array}$ & $\begin{array}{c}352 \\
(23.1)\end{array}$ \\
\hline 9 & $\begin{array}{c}341 \\
(22.2)\end{array}$ & $\begin{array}{c}336 \\
(24.6)\end{array}$ & $\begin{array}{c}324 \\
(15.1)\end{array}$ & $\begin{array}{c}338 \\
(26.8)\end{array}$ & $\begin{array}{c}347 \\
(29.4)\end{array}$ & $\begin{array}{c}379 \\
(20.2)\end{array}$ & $\begin{array}{c}328 \\
(15.5)\end{array}$ & $\begin{array}{c}394 \\
(28.4)\end{array}$ & $\begin{array}{c}384 \\
(17.4)\end{array}$ & $\begin{array}{l}365 \\
(17.2)\end{array}$ \\
\hline 10 & $\begin{array}{c}447 \\
(14.4)\end{array}$ & $\begin{array}{c}427 \\
(13.4)\end{array}$ & $\begin{array}{c}410 \\
(16.7)\end{array}$ & $\begin{array}{c}443 \\
(19.4)\end{array}$ & $\begin{array}{c}446 \\
(32.9)\end{array}$ & $\begin{array}{c}497 \\
(18.5)\end{array}$ & $\begin{array}{c}410 \\
(20.0)\end{array}$ & $\begin{array}{c}432 \\
(14.0)\end{array}$ & $\begin{array}{c}424 \\
(11.1)\end{array}$ & $\begin{array}{c}455 \\
(12.2)\end{array}$ \\
\hline 11 & $\begin{array}{c}251 \\
(8.7)\end{array}$ & $\begin{array}{c}236 \\
(8.8)\end{array}$ & $\begin{array}{c}261 \\
(15.0)\end{array}$ & $\begin{array}{c}241 \\
(10.6)\end{array}$ & $\begin{array}{c}231 \\
(8.6)\end{array}$ & $\begin{array}{c}285 \\
(19.4)\end{array}$ & $\begin{array}{c}237 \\
(7.6)\end{array}$ & $\begin{array}{c}255 \\
(7.9)\end{array}$ & $\begin{array}{c}269 \\
(6.6)\end{array}$ & $\begin{array}{c}255 \\
(10.0)\end{array}$ \\
\hline 12 & $\begin{array}{c}258 \\
(8.7)\end{array}$ & $\begin{array}{c}259 \\
(10.5)\end{array}$ & $\begin{array}{c}289 \\
(14.9)\end{array}$ & $\begin{array}{c}246 \\
(8.5)\end{array}$ & $\begin{array}{c}247 \\
(9.8)\end{array}$ & $\begin{array}{c}347 \\
(38.8)\end{array}$ & $\begin{array}{c}254 \\
(9.7)\end{array}$ & $\begin{array}{c}327 \\
(20.8)\end{array}$ & $\begin{array}{c}290 \\
(9.6)\end{array}$ & $\begin{array}{c}279 \\
(8.3)\end{array}$ \\
\hline Mean & 295 & 299 & 305 & 299 & 307 & 346 & 297 & 319 & 314 & 314 \\
\hline
\end{tabular}

- Tabular meanings same as Table 2.

word was "green." If one operationally defines "colorimetric discrepancy" as either the number of Munsell hue steps between two hues, or perhaps more appropriately, the chord length across the color wheel, there is considerably less discrepancy among the blue, blue-green, and green hues used in this experiment than between the red, purple, and blue hues. Thus the pattern of the data from the 20-msec-delay group could be satisfactorily predicted from a model involving a variety of colorimetric distance measures between the hue named by the word and the background color of the word display.

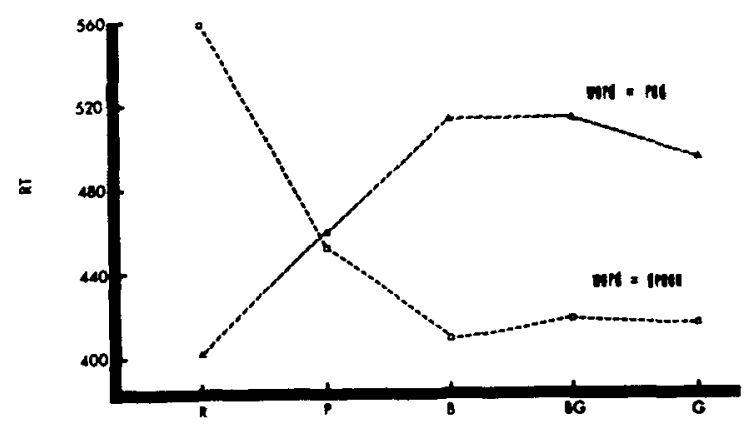

BACKGROUND

Figure 3. Mean RT plotted as a function of word and background color for the 20 -msec.delay group in Experiment II.

\section{GENERAL DISCUSSION}

Both experiments demonstrate an interference phenomenon in which speed of performance is slowed by the failure to gate an irrelevant sensory attribute (an incongruent color) rather than an irrelevant linguistic attribute (such as an incongruent color name). Failures of selective attention which allow such interference are thus not limited to linguistic input (such as the unwanted reading occurring in the traditional Stroop test), but include sensory processing as well. In addition, both of the present

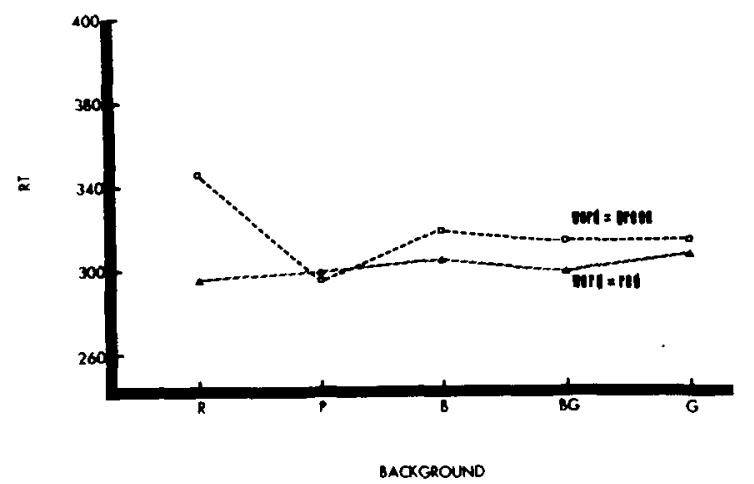

Figure 4. Mean RT plotted as a function of word and background color for the 500-msec-delay group in Experiment Ii. 
experiments show that these interference effects are reduced or eliminated by providing a sufficient delay between the two stimulus components to be matched, strongly suggesting that the interference rests in the process of transforming the representation of the first half of the stimulus sequence into a form which can be efticiently compared with the second half of the stimulus. Since the task required matching a word (displayed first) to a color (displayed secondly), this transformation would logically appear to be from a linguistic to a pictorial mode.

Most previous interpretations of Stroop-like interference phenomena have been based upon verbal response competition, even from covert stimulus naming (Dalrymple-Alford \& Azkoul, 1972). One might thus argue that, with a brief delay between the word and color choice field, subjects attempt to use a name code rather than a pictorial code to make the match, and that interference results from implicit naming of the irrelevant color. However, the implicit naming of ink colors, if it occurs at all, has little or no effect on the oral reading of color words (Stroop, 1935). and it is difficult to see why such naming would disrupt covert reading of a relevant word. In general, forming linguistic representations from words seems to be much more rapid than forming linguistic representations from objects; or at least reading is generally more rapid than naming (Fraisse, 1969). Thus it appears unlikely that an unintentional naming would delay an intentional reading in a speeded task. Furthermore, if the irrelevant colors were, in fact, named, one would expect maximum interference from highly "nameable" colors. In Experiment 1I, the large amount of interference caused by the blue-green background when the word was "red" is not consistent with this prediction (e.g., Berlin \& Kay, 1969). On the other hand, 4BG is nearly the sensory compliment of 5R. Thus the "generalization" data from Experiment II tend to support a sensorypictorial interference interpretation as opposed to a verbal response competition model.

Verbal response competition from covert stimulus naming may play an important role in the performance of other types of classification and discrimination tasks for which no overt naming response is required, particularly if the task imposes a substantial processing load (Hock \& Egeth, 1970; Morton, 1969). In such tasks, verbal coding of visual stimuli may perhaps be forced by the item limitations of active visual memory, or by the complexity of the response assignments. In the present case, only a simple stimulus match was required, and the observed interference would appear to be parsimoniously interpreted as competition between visual sensation and the pictorial encoding of a verbal stimulus.

\section{REFERENCES}

Berlin. B., \& Kay, P. Basic color terms: Their universality and ('volution. Berkeley: University of California Press, 1969.

Bindra, D., Donderi, D. C., \& Nishisato, S. Decision latencies of "same" and "different" judgments. Perception \& Psychophysics. 1968. 3. 121-130.

DalRym Ple-Alford, E. C., \& Azkoul, J. The locus of interference in the Stroop and related tasks. Perception \& Psychophysics, 1972, 11, 385-388.

DYER. F. N. The Stroop phenomenon and its use in the study of perceptual. cognitive, and response processes. Memory and Cognition. 1973, 1, 106-120. (a)

DYER, F. N. Same and different judgments for word color pairs with "irrelevant" words or colors: Evidence for word-code comparisons. Journal of Experimental Psychology, 1973, 98. 102-108. (b)

Egeth, H. E., Blecker, D. L., \& Kamlet, A. S. Verbal interference in a perceptual comparison task. Perception \& Psychophysics, 1969, 6. 355-356.

Fraisse, $\dot{P}$. Why is naming longer than reading? Acta Psychologica, 1969. 30. 96-103.

Hork. H. S.. \& EGETH, H. E. Verbal interference with encoding in a perceptual classification task. Journal of Experimental Psychology. 1970, 83, 299-303.

Morton, J. Categories of interference: Verbal mediation and conflict in card sorting. British Joumal of Psychology, 1969. 60. 329-346.

Posner, M. I., Boise, S. J., Eichelman, W. H., \& TAylor, R. L. Retention of visual and name codes of single letters. Journul of Experimental Psychology Monograph. 1969, 79, 1-13.

ReED. S. K. Psychological processes in pattern recognition. New York: Academic Press, 1973.

SHOR, R. G. The processing of conceptual information on spatial directions from pictorial and linguistic symbols. Acta Psychologica, 1970. 32. 346-365.

Stroop, J. R. Studies of interference in serial verbal reactions. Journal of Experimental Psychology, 1935, 18, 643-662.

Treisman. A. M.. \& Fearnley, S. The Stroop test: Selective attention to colours and words. Nature, 1969, 22, 437-439.

TVERsKy, B. Pictorial and verbal encoding in a short term memory task. Perception \& Psychophysics, 1969, 6, 225-233.

Uleman, J. S.. \& Reeves, J. A reversal of the Stroop effect through scanning. Perception \& Psychophysics, 1971, 9, 293-295.

WARREN. R. E., \& LASHER, M. D. Interference in a typeface variant of the Stroop test. Perception \& Psychophysics, 1974, 15. $128-130$.

\section{NOTES}

1. Error rates varied from .000 to .058 across conditions and were thus far too low to permit a meaningful analysis.

2. The actual number of stimulus presentations for which data was obtained from each subject for each combination of word and backgrou nd colo varied from 14 to 20 , since a few trials were "lost" due to response errors and equipment malfunctions. Group presentation did not permit the reinsertion of stimulus seuences. However, these losses were essentially equally distributed across conditions and the true " $\mathrm{N}$ " for each subject was used in computing the means and SEs listed in Tables 2 and 3.

3. Error rates were again extremely low, ranging from .000 to .051 at the 20 -msec delay, and from .004 to .025 at the 500 -msec delay.

(Received for publication January 31, 1975: accepted April 2, 1975.) 